\title{
The Bedouin Refugees in the Negev
}

\author{
Aref Abu-Rabia
}

\section{Introduction}

Most of the researchers who studied the Bedouin's history in the Negev agree that the Bedouin arrived to the Negev and Sinai from the Arabian Peninsula, and that some of them had arrived before the expansion of Islam in the 7th century. The Bedouin had three main reasons for migration: searching for grass and water sources for themselves and their livestock; avoiding blood revenge; and expansion of Islam in the 7th century. The social structure of the tribe, by ascending hierarchy, is as follows: the nuclear family, the extended family, the subtribe, the tribe, and the clan (federation of tribes). The traditional Bedouin family is patrilineal, patrilocal, patriarchal, endogamous, and occasionally polygamous.

The Negev Desert occupies some 12,500 sq. km. The Negev Bedouin dwell in an area of $1,000 \mathrm{sq}$. $\mathrm{km}$. of which some 40 percent are range lands. This area is semi-arid and serves the Bedouin population for dwelling, grazing, and dry farming. The climatic conditions in the Negev are harsh for the vegetation, but they vary from year to year. The amount of rainfall decreases gradually from North to South, from 200-25 mm.

At the end of the British Mandate, the Bedouin population of the Negev numbered between 65,000 and 100,000 (Abu-Khusah 1979, Abu-Rabia 1994, Israel Army 1954, Marx 1967, Muhsam 1966, Shimoni 1947). These Bedouin belonged to 95 tribes which were part of the great clans or tribal confederations: Tiaha, Zullam, Tarabin, 'Azazmeh, 'Hanajreh, Jbarat, Sa'idiyeen, $A^{\prime}$ heiwat, and Jahalin (al-'Aref

\footnotetext{
Aref Abu-Rabia, Department of Behavioural Sciences, Ben-Gurion University of the Negev, Beer-Sheva, Israel.
}

1934, Marx 1967). When the Israeli Army occupied the Negev in 1948, the majority of the tribes were expelled to Jordan, the Gaza Strip, and Sinai (Marx and Sela 1980, Diqs 1967, Higgins 1969). Other Bedouin, who were afraid of the Israeli authorities, especially because they had participated in battles against Israel, left of their own accord. The situation remained unstable until 1953, when only about 11,000 Bedouin were left in the Negev. Most of the Bedouin tribes that remained behind were remnants of tribes or branches of tribes which joined together around nineteen heads of tribes recognized by the Israeli authorities as chiefs (sheikhs). The Israeli authorities concentrated the Bedouin under military rule in the northeastern Negev, in a closed area (Sayig). A special permit had to be obtained from the authorities to enter or leave the area or to move within the region between one tribe and another. In this way, the authorities ensured that they had complete control over the Bedouin. Sheikhs, notables, and other friends of the authorities were given special permits which allowed them freedom of movement out of the closed area, on the condition that they returned to the tribe by evening. It should be noted that, after the cancellation of military rule in 1966, most of the Bedouin continued living in the former closed area.

The Bedouin land ownership has been a legal issue at least since the days of the Ottoman rule in the Negev and the Palestine. The Bedouin did not know then that the legal status of lands as laid down in Turkish law would be of significance one hundred years after it was originally defined by the Turks (Boneh 1983, p.111-25). The lands taken by the government were considered to be its property or under its control and administration. Ottoman rule permitted those using the land to work it according to law, which included paying property tax and obtaining permission from the state for every transaction. A law enacted in 1856 classified the land into five categories: private lands (mulk); lands for agriculture or pasturage, but not for building purposes (miri); lands of the Moslem religious institutions (waqf); lands for public purposes such as crossings and public roads (matruka); and waste lands or lands which were not owned by anyone (mawat). To work mawat lands, permission had to be obtained from the Government, and the lands had to be registered. It must be remembered that only according to the legal definition was land considered to be mawat land unfit to be cultivated. When the legal definition was amended in 1921, it was no longer possible to purchase or obtain rights to these lands, even by working them (Atran 1987, Aumann 1975, Bahjat 1974, Bergheim 1895, Granott 1952, Hope-Simpson Report 1930, GrahamBrown 1980, Lewis 1987, Stein 1984).

Nevertheless, in practice, the British Mandatory authorities recognized the ownership of land by the Bedouin, and levied taxes on them on cultivated lands. Moreover, these lands became subject to sale. They were measured and registered in the land registry books; among such registered transactions were sales to the Keren Kayemet (Jewish National Fund) through Arab agents (Bresslavsky 1946, 34-91). But most Bedouin lands were not registered with the Land Registry Office, and the authorities classified the lands as mawat. According to al-Aref, the reasons for non-registration of lands were fear of the burden of government taxes, abhorrence of revealing details of private property, and the fact that the Bedouin saw no sense in registering their property on paper as proof of ownership. At that time proof, quite simply, lay in the sword. So in practice, most of the lands of the Negev were 
defined as mawat (al-Aref 1933, 235$40)$. But the real problem lay elsewhere: the extensive areas of the Negev had simply not yet been surveyed, and could not therefore be registered, except when specific blocks of land were surveyed, usually in connection with a sale.

During British rule, the Bedouin cultivated their lands almost without interference from the authorities. The Israeli authorities adopted Ottoman law, especially in connection with mawat lands. The policy of the Israeli Lands Administration was to attempt to prevent the Bedouin from striking root in their traditional areas in the 1960s; they also sought to settle them in planned modern towns in order to vacate the land more rapidly. Today, most of the land in the Negev is held by the Lands Administration (Marx and Sela 1980, Fenster 1980). Of the approximately two million dunam cultivated by the Bedouin before the establishment of the State of Israel, about $1,800,000$ dunam are in the hands of the Administration, while the Bedouin hold the rest. Almost all the land held by the Administration has been handed over to Jewish settlements in the western Negev; only about 400,000 dunam of cultivable land is in the closed area, where it is hired out to the Bedouin in small plots and on a seasonal basis. The Bedouin believe that they are owners of the land cultivated by them and that they have pasturage rights in additional areas. This right is based, in their opinion, on their forefathers seizing the land (hajr) hundreds of years ago, and on its cultivation by subsequent generations (alAref 1993, 1994; Kressel, Ben-David, Abu-Rabia 1991).

As a result of the Camp David Treaty between Israel and Egypt in 1979, Israeli air bases in the Sinai desert had to be evacuated so that the area could be returned to Egypt. A site for the construction of a new airfield was chosen in the Tel al-Malah area, on the eastern portion of the Beer-Sheva ba$\sin$. The government had to enact a special law that would enable it to start work in the area and settle the Bedouin land problem. The initially proposed law called for the appropriation of some 300,000 dunams, almost four times the size needed for the construction of the airfield itself (Marx 1979, 6). After reconsideration of several aspects of the law, and with the input of scholars and specialists, a new version of the law was passed in the Israeli Parliament in 1980. The law stated the terms of a negotiated settlement with owners of land in the Tel al-Malah area. Drafters of the legislation intended that, once the law was implemented in Tel al-Malah, it would be extended to other areas where land problems still exist.

In its present version, the law relates only to those Bedouin who live in Tel al-Malah or cultivate land there. But it is the stated intention of the law to apply to Bedouin groups in other areas, so that a future agreement with them may become possible (Boneh 1983). In addition to land agreements with Bedouin in Tel al-Malah, and the recognition given to Bedouin as landclaimers, drafters of the law stated their intention to raise some hope for a land agreement with Bedouin groups who were previously owners of lands but were evacuted from them between 1948 and 1953 (Ben-Meir Commission Proposal 1980, 1). The recognition of the problem as relating to three different categories within the Bedouin population is important. As with the consequences of the forced evacuation and concentration of the Bedouin following the war of 1948 , tribes from different areas have lived in different circumstances. Those Bedouin who have stayed on their lands, and are the subjects of the present land settlement attempts at Tel al-Malah, differ from those whose land was confiscated or its use restricted. And these two groups are different from those that were evacuated between 1948 and 1953 from areas outside the closed zone and were relocated (Boneh 1983).

The Bedouin population in the Negev in 1994 is about 85,000, comprising 40 tribes. About 40,000 live in seven permanent urban settlements planned by the authorities: Rahat, Laqia, Hura,
Tel-Sheva, Shgib, 'Aroer, and Ksifa. Some 35,000 dwell in wooden or tin huts, or concrete block houses, scattered within the various tribal areas. About 10,000 still live in tents and wander with their flocks of livestock and camels. Education plays a key role in their adaptation to the socioeconomic changes and to a new lifestyle. There has been progress in the number of schools and teachers provided, the number of children in the schools, the attendance of girls, the awareness of parents of the importance of education, and the willingness of parents to send their children to schools. In June 1994, there were 40 schools, 4 of them secondary; 25,000 students from kindergarten to 12 th grade-14,000 boys, and 11,000 girls, with female students' share being $47,41,37$, and 31 percent in grades $1,8,9$, and 12 , respectively.

The Bedouin diet is changing. Although bread was, and remains, the dietary staple, Bedouin are now freed from their previous dependence on seasonal produce. They consume more dairy products, more meat and poultry, take more sugar in their tea and coffee, and use more cooking oil in place of the traditional Samin-clarified livestock butter. They also smoke more. What is all this doing to the Bedouin? In some ways, the Negev Bedouin are beginning to resemble their fellow Israelis and are starting to acquire some of the latter's ailmentsheart disease, ulcer, high blood pressure, stress, and diabetes mellitus. There are ten modern clinics serving the Bedouin population, in the urban and tribal settlements. They use the services of these clinics in case of illness, immunization, and primary health care. In case of hospitalization, the Beer-Sheva Soroka Hospital is at their service. In traditional and folk medicine, the Bedouin appeals to the dervish; the khatib-the writer of amulets; the cauterizer; the mujabbirsetting of broken or fractured bones; the herbalist; midwives; 'attar-local pharmacologist, vendor of medicinal spices.

No one knows the actual number of the Bedouin currently living in Gaza, 
but by late 1948 and early 1949 some 32,000 Bedouin had arrived in the Gaza area from Beer-Sheva and the Negev Desert as refugees. Some 3,000 had also arrived from the Ramleh and Jaffa areas. The current population could be as high as 60,000 . In accordance with their lifestyle, the Bedouin tend to live on the edges of populated areas, away from clinics, offices, and schools, and havelittle intercourse with other members of the population. Many live in makeshift shelters which are inadequate for winter cold and storms. They have tended to settle near groves and orchards, and often maintain small gardens so that some fruit and vegetables are available. There are no statistics relating to the health of the Bedouin living on the Gaza strip, but because of their isolation, wariness of strangers, and lack of money, adequate medical assistance is difficult for them to obtain. The nearest medical clinic is frequently several kilometers away and the nearest hospital much farther. They are basically a healthy group of people, but particular health problems do occur which, if treated, would greatly improve the quality of life of many families.

There are no up-to-date statistics relating to the Bedouin refugees living on the Western and Eastern Banks. In Jordan, most Palestinian refugeesincluding the Bedouin-gained citizenship (Brynen 1990). People may, however, retain their refugee status long after they have adapted to a new environment. But by then the meaning of being a refugee may have changed. During the earlier phase, refugeedom may have referred to their dependence, while later it may mean that the refugees organize as "refugees" in order to negotiate better with the state (Marx 1990). There are pressing problems of refugees in many parts of the world, which require answers and solutions. One of these pressing problems is the Negev's Bedouin refugees. There is a need to examine the exact nature, numbers, and conditions of the Bedouin refugees in the Gaza Strip, the West Bank, and Jordan; to describe the impact of the "Requisition of Land in
Negev Law, 1980" (Peace Treaty with Egypt) on the Bedouin lands of the Negev; to examine Bedouin and Israeli land problems and possibilities for a regional solution; to determine the implications of Palestinian autonomy for the status of the Bedouin in Israel; to examine possible actions for compensation to Bedouin refugees in the Negev, Gaza Strip, the West Bank, and Jordan through the current peace process and negotiations between the Palestinians and the Israelis; to determine how many Bedouin refugees would want to return to their home lands in the Negev; and to investigate the role that Israel, the United States, European, and Arab countries might play in solving the problems of Bedouin refugees.

\section{Bibliography}

Abu-Khusa, A. Bi'r al-Sab'a wal-hayah alBadawiya, Amman: Matabi' al-Mu'assasa al-Sahafiya al-Urdunniya, 1976-1979 (in Arabic).

Abu-Rabia, A. 1994. The Negev Bedouin and Livestock Rearing: Social, Economic and Political Aspects. Oxford: Berg.

Al-Aref, A. 1993. Al-Qada bayna al-Badw. Jerusalem.

—. 1994. Tarikh Bi'r al-Sab'a wa-Qabai' liha. Jerusalém.

Atran, S. 1987. "Hamula Organization and Masha' Tenure in Palestine." Man vol. 21, pp. 271-95.

Aumann, M. 1975. "Land Ownership in Palestine 1880-1949." In The Palestinians, edited by $M$. Curtis. New Brunswick: Transition Books.

Bahjat, H. "The Social and Economic Development in the Jerusalem District 1840-1873." In Society and Heritage vol. 1, no. 3; al-Bireh: The Palestinian Folklore and Social Research Society In'ash al-Usra, 1974, pp. 92100.

Ben-David, J. 1982. "Stages in the Sedentarization of the Negev Bedouin, a Transition from Semi-Nomadic to Settled Population." Ph.D. Thesis, The Hebrew University of Jerusalem.

Ben-Meir Commission. 1980. Proposal for Bedouin Resettlement. Implementation Authority, Tel Aviv: TAHAL (in Hebrew).

Bergheim S. 1985. "Land Tenure in Palestine." Palestine Exploration Fund Quarterly Statement pp. 191-99.

Boneh, D. 1983. "Facing Uncertainty: The Social Consequences of Forced Sedentarization among the Jaraween Bedouin, Negev,
Israel." Ph.D. Dissertation, Department of Anthropology, Brandeis University.

Bresslavsky, M. 1946. Do you know the country. B: The Negev. Tel-Aviv: Hakibutz Hameuchad (in Hebrew).

Brynen, R. 1990. "The Politics of Exile: The Palestinians in Lebanon." Journal of Refugee Studies vol. 3. no. 3.

Diqs, I. 1967. A Bedouin Boyhood. London: Allen and Unwin.

Falah, G. 1989. "Israel State Policy towards Bedouin Sedentarization in the Negev." Journal of Palestine Studies vol. XVIII, no. 2 , issue 70.

Fenster, T. "Evacuation and Resettlement of the Bedouin of Tel-Milhata." Implementation Authority, Tel Aviv: TAHAL, 1980-1984 (in Hebrew).

Graham-Brown, S. 1980 . Palestinians and Their Society 1880-1946. London: Quartet Books.

Granott, A. 1952. The Land System in Palestine. London: Eyre and Spottiswoode.

Higgins, R. 1969. United Nations Peacekeeping 1946-1967 Documents and Commentary Vol. I. London: Oxford University Press.

Hope-Simpson Report. 1930. Palestine: Report on Immigration, Land, Settlement and Development. London: HMSO.

Israel Army 1954. Beduei ha-Negev bi-Medinat Israel. Tel Aviv: IDF.

Khogali, M. M. 1981. "Sedentarization of the Nomads: Sudan." The Future of Pastoral People, edited by J. G. Galaty et al.

Kressel, G., Ben-Daviv, J. and Abu-Rabia, Kh. 1991. "Changes in the Land Usages by the Negev Bedouin since the Mid-19th Century." Nomadic Peoples no. 28.

Lewis, N.,N. 1987. Nomads and settlers in Syria and Jordan, 1800-1980. Cambridge: Cambridge University Press.

Marx, E. 1967. Bedouin of the Negev. Manchester: Manchester University Press.

- 1990. "Advocacy in a Bedouin Resettlement Project in the Negev, Israel," in Anthropology and Development in North Africa and the Middle East, edited by M. SalemMurdock and M. Horowitz. Boulder, San Fransisco, and Oxford: Westview Press.

_ 1990. "The Social World of Refugees: A Conceptual Framework." Journal of Refugee Studies vol. 3. no. 3.

Marx, E. and Sela, M. 1980. "The Situation of the Negev's Bedouin-Appendix No.1." BenMayer's Team for Evacuation and Resettlement of the Bedouin. Tel Aviv: TAHAL.

Muhsam, H. V. 1966. Bedouin of the Negev: Eight Demographic Studies. Jerusalem: Academic Press.

Shimoni, Y. 1947. 'Arvei Erts-Israel. Tel Aviv: 'Am 'Oved.

Stein, K. 1984. The Land Question in Palestine: 1917-1939. Chapel Hill: University of North Carolina Press. $\sqsupset$ 